\title{
Characterization of the Campylobacter fetus subsp. venerealis Adhesion to Bovine Sperm Cells
}

\author{
Caracterización de la Adhesión de Campylobacter fetus subsp. venerealis a Espermatozoides Bovinos
}

\author{
María L. Chiapparrone*; Pedro Soto* \& María Catena*
}

ChIAPPARRONE, M. L.; SOTO, P. \& CATENA, M. Characterization of the Campylobacter fetus subsp. venerealis adhesion to bovine sperm cells. Int. J. Morphol., 34(4):1419-1423, 2016.

SUMMARY: Campylobacter fetus is extracellular bacteria of the genital tract of cattle. They cause infertility and abortion, but there is no documented information on the susceptibility of bovine sperm cells to this bacteria. The aim of this present work was to study the effects provoked by Campylobacter fetus subsp. venerealis when in interaction with bovine sperm cells. The bovine spermatozoa were obtained frozen bovine semen pooled from uninfected bulls, and were exposed to living campylobacter over different periods of time. Light microscopy and scanning electron microscopy first revealed a tropism, then a close proximity followed by tight adhesion between these two different cells. A decrease in the spermatozoa motility was observed. Motile bacteria were observed during the next 3 $\mathrm{h}$, this process began with a tight membrane-membrane adhesion. The adhesion between Campylobacter fetus to the sperm cell occurred either by the flagella or by sperm head. Results from this study demonstrated with light microscopy scanning electron microscopy allowed us to characterize some aspects of the interaction of Campylobacter fetus subsp. venerealis and bovine sperm while preserving the cellular and bacterial structure. This ex vivo model might be useful for studies on adhesion and cytopathogenicity of different field strains of Campylobacter fetus.

KEY WORDS: Adhesion; Campylobacter fetus subsp. venerealis; Sperm cells.

\section{INTRODUCTION}

Successful mammalian reproduction requires that sperm migrate through a long and convoluted female reproductive tract before reaching oocytes. For many years, fertility studies have focused on biochemical and physiological requirements of sperm (Barth, 1995). There are a large number of microorganisms that propagate for the seminal route. The pathogen can adhere to the sperm in the tail and/ or the head, or can infect the various components of the seminal fluid as sperms, seminal plasma and leukocytes, among others) (Bielanski \& Dubuc, 1993; Bielanski et al., 1994; Bielanski \& Dubuc, 1994; Bielanski \& Loewen, 1994; Bielanski et al., 2004). Many of the existing studies on the association pathogen-sperm are not conclusive because, the detection of this union is complex and in some in some cases uncertain (Casadevall \& Pirofski, 2000) as in the case of Campylobacter fetus (Bielanski et al., 1994).

In the project of ex vivo model for the study of the pathogenesis of the bovine genital campylobacteriosis (Chiapparrone et al., 2008; Chiapparrone et al., 2009; Chiapparrone et al., 2011; Chiapparrone et al., 2014) intends to describe the behavior of a strain of Campylobacter fetus subsp. venerealis (C. fetus subsp. venerealis) bacteria of preputial smegma of bull in its interaction with sperm cattle by light microscopy and scanning electron microscopy (Fletcher \& Floodgate, 1973).

\section{MATERIAL AND METHOD}

Bacterial strain. The $C$. fetus subsp. venerealis strain was isolated in beef bovine of Tandil - Argentina, from preputial tract of Aberdeen Angus bull and identified using phenotypic test and PCR. The strain was grown for $48 \mathrm{~h}$ at $37^{\circ} \mathrm{C}$ incubated under microaerophilic conditions which correspond to the logarithmic growth phase. All experiments

Laboratorio de Microbiología Clínica y Experimental, NACT. SAMP, Unidad Ejecutora de CONICET (CIVETAN). Facultad de Ciencias Veterinarias. Universidad Nacional del Centro de la Provincia de Buenos Aires, Argentina. 
were performed with $C$. fetus subsp. venerealis-1 strain at a concentration of $1 \times 10^{9}$ cells $/ \mathrm{mL}$.

Sperm cells. We used frozen bovine semen pooled from fertile bulls for artificial insemination. For interaction purposes, straws of frozen semen were thawed by immersion in a water bath at $37^{\circ} \mathrm{C}$ for $30 \mathrm{~s}$, centrifuged and the entire medium removed. The cells were washed once in PBS and transferred to Minimum Essential Medium Eagle (MEM) culture medium (M0643 Sigma-Aldrich) supplemented with $10 \%$ fetal bovine serum.

Viability tests were based on visual morphology and motility under dark field microscopy, each sperm cell was categorized as belonging to one of four motility categories (rapid progressive, slow progressive, non-progressive and immotile) and viability staining with Nigrosin-Eosin stain (Rodríguez-Martinez, 2013).

Adherence assay. For interaction analysis, suspensions of sperm cells were counted in a Neubauer chamber and exposed to $C$. fetus subsp. venerealis-1 in a cell ratio of $1: 1$ bacteria-sperm cells, for $3 \mathrm{~h}$ at $37^{\circ} \mathrm{C}$ incubated under $5 \%$ $\mathrm{CO}_{2}$. For control experiments, the same bacteria and sperm cells free were used. The bacterial motility can be determined under dark field microscopy.

Giemsa stain. Sperm cells were fixed with acetone at $4^{\circ} \mathrm{C}$ and stained with Giemsa $10 \%$. Bacterial adhesion was observed and quantified by optical microscopy.

Scanning electron microscopy. After checking the adhesion by Giemsa staining, innoculated cell cultures were processed according to Electron Microscopy Laboratory protocol of the College of Sciences, Universidad Nacional de Mar del Plata (UNMdP). Briefly, the sperm cells were fixed with 3 $\%$ glutaraldehyde in sodium cacodylate buffer and washed with $0.1 \mathrm{M}$ sodium cacodylate buffer. After dehydration with ethanol they were exposed to hexamethyldisilazane overnight, and then gold and palladium metallizing (Denton Vacuum Desk II). The samples were observed with scanning electron microscope (Jeol JSM-6460 LV). The system used was an EDAX Genesis XM4 - Sys 60, equipped with Multichannel Analyzer EDAX mod EDAM IV, Sapphire Si (Li) detector and super ultra-thin Window of Be, and EDAX Genesis version 5.11 software.

\section{RESULTS}

Of the sperm cells $78 \%$ were alive, before bacteria sperm interaction. This number reduced to $56 \%$ in the third

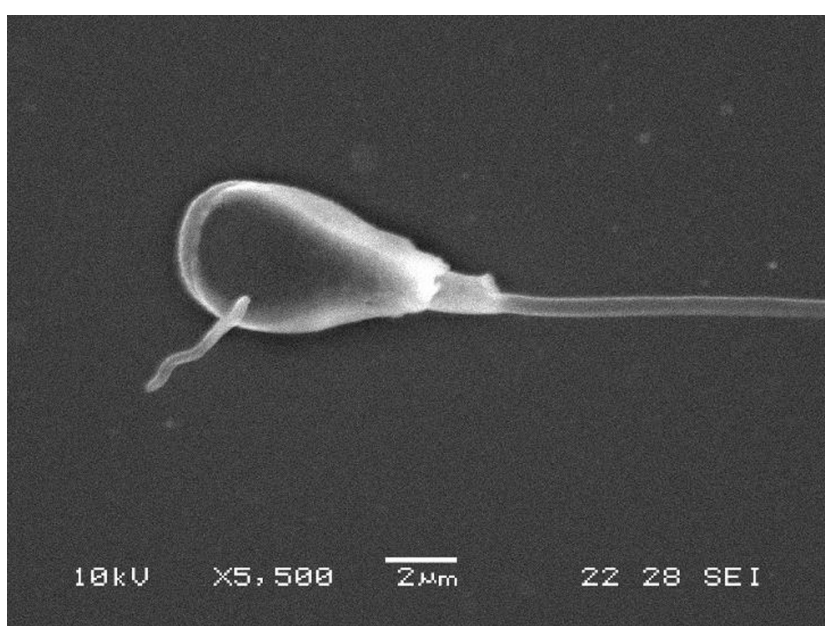

Fig. 1. Campylobacter fetus subsp. venerealis adhered to head of sperm cells for the apical end. Scanning electron microscopy. $5500 \mathrm{X}$.

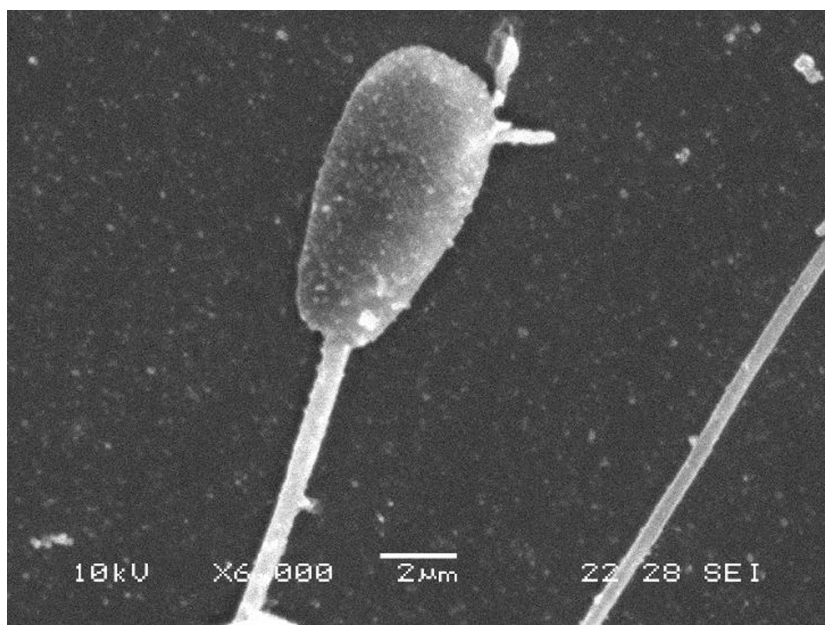

Fig. 2. Campylobacter fetus subsp. venerealis adhered to head of sperm cells for the apical end. Scanning electron microscopy. $6000 X$.

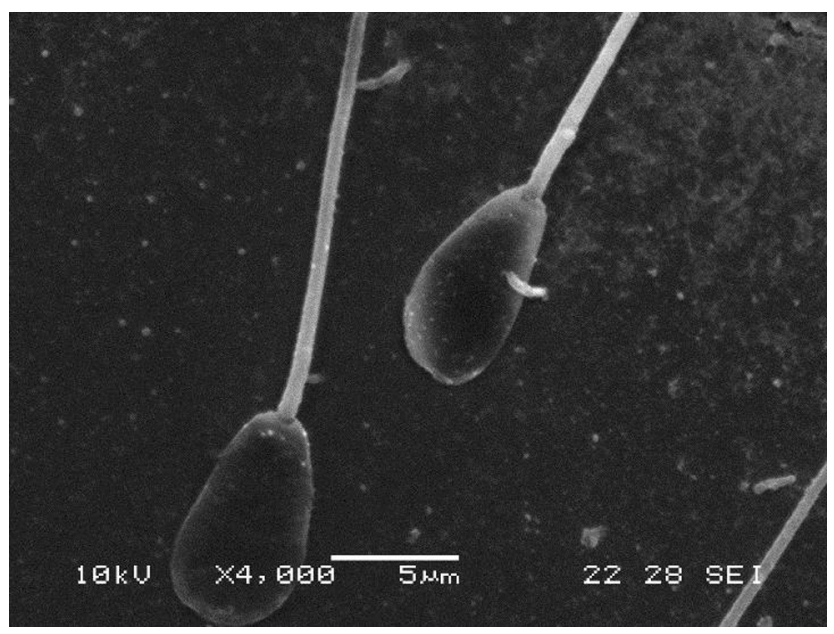

Fig. 3. Campylobacter fetus subsp. venerealis adhered to head and tail of sperm cells for the apical end. Scanning electron microscopy. 4000X. 
hour, when bacteria and sperm cells were under interaction. Sperm that were white (unstained) were classified as alive, and those that showed any pink or red coloration were classified as dead, with the sole exception for sperm with a slight pink or red appearance restricted to the neck region ('leaky necks'), which were assessed as live. Motile bacteria were observed during the next $3 \mathrm{~h}$.

By scanning electron microscopy sperm cell treated with $C$. fetus subsp. venerealis showed adhesion and alterations in the bovine spermatozoa. All the superficial structures of spermatozoa such as head (66\%), mid piece, neck, and tail (34\%) were involved in bacterial adhesion.

The capacity of adherence to different parts of the sperm, the number of adherent $C$. fetus subsp. venerealis and the characteristics of interaction were analyzed. In the images,

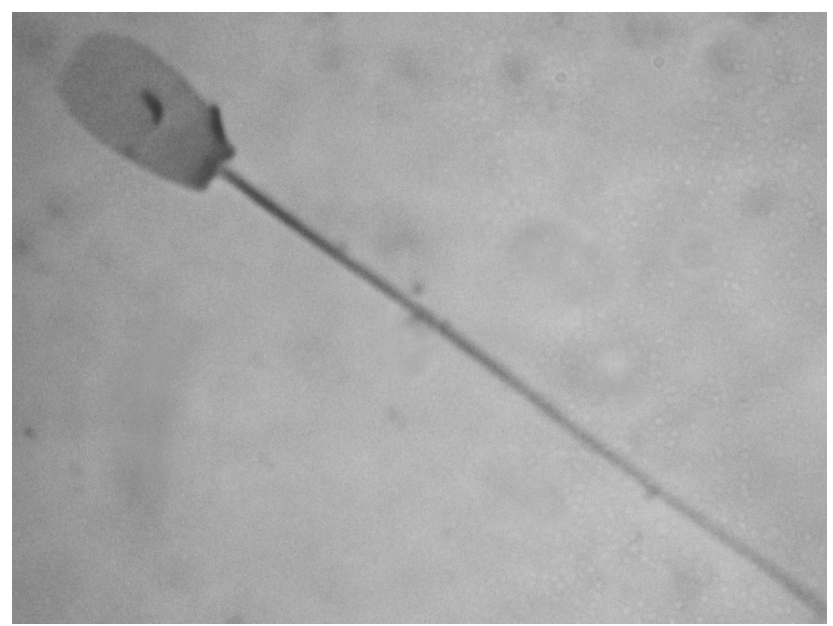

Fig. 4. Campylobacter fetus subsp. venerealis adhered to head of sperm cells. Giemsa stain. 100X.

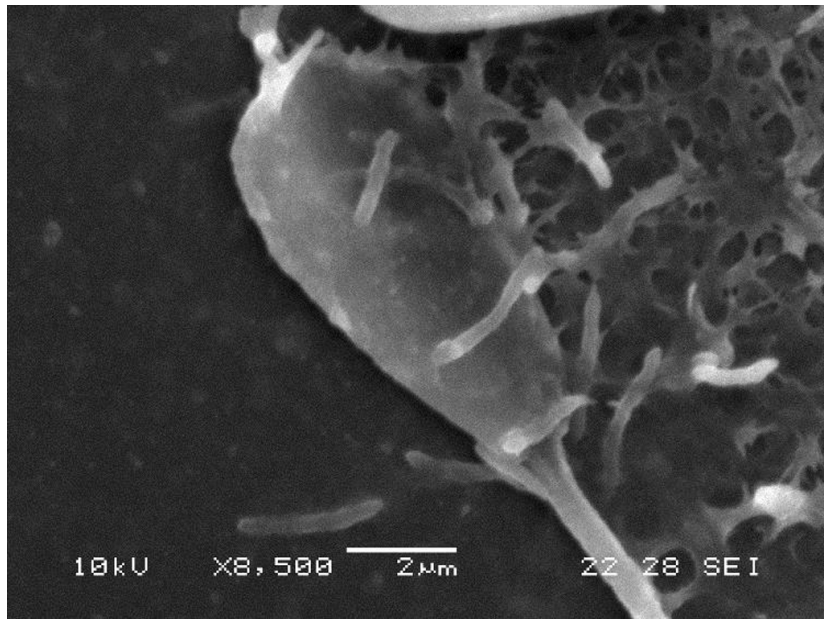

Fig. 5. Observation of more than one Campylobacter fetus subsp. venerealis adhered to sperm cells. Scanning electron microscopy. $8500 \mathrm{X}$. the presence of one or more $C$. fetus subsp. venerealis adhered by the apical body, mainly to the sperm head (Figs 1,2 and 3), was observed and confirmed by routine colorations (Fig. 4). In others cases, it was possible to determine the presence of bacterial shapes in an extracellular matrix, adhered to the external membrane of the head and tail of sperm, grouping with biofilm characteristics (Figs. 5 and 6).

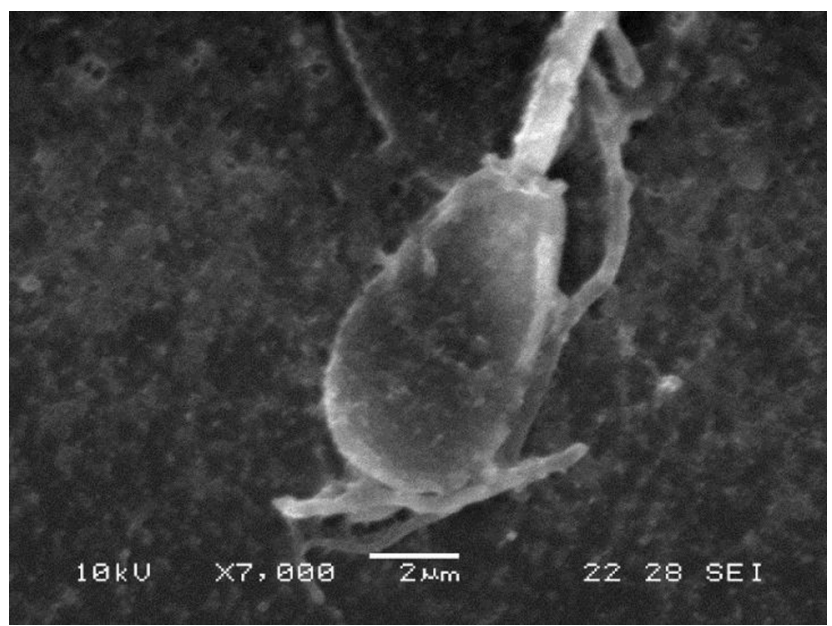

Fig. 6. Observation of grouping of Campylobacter fetus subsp. venerealis adhered to head of sperm cells. Scanning electron microscopy. 7000X.

\section{DISCUSSION}

C. fetus subsp. venerealis is one bacteria that cause infertility in cows (Campero, 2002; Catena, 2002; Catena, 2003). However, there is no documented information about Campylobacter effect on sperm cells viability (Bhavsar \& Kapadnis, 2006; Brenner et al., 2005; de Melo \& Pechére, 1990; Graham \& MacDonald, 1988; Joens et al., 2010) and there is no complete agreement on the detrimental role of bacteria presence in the semen.

The ability of bacteria to bind to host cells is important as it represents an early event in the creation establishment in vivo microorganism - cell relationship (Casadevall \& Pirofski, 2000; Benchimol et al., 2008; Chiapparrone et al., 2014). Sometimes, such binding process is also a requirement for pathogenicity. Understanding the capability of adherence of C. fetus subsp. venerealis to the host cell (Chiapparrone, 2011) is significant for a thorough knowledge of the initial steps involved in the pathogenesis of bovine genital campylobacteriosis.

The light microscopy and scanning electron microscopy allowed us to characterize some aspects of the interaction of C. fetus subsp. venerealis and bovine sperm while preserving the cellular and bacterial structure. 


\section{ACKNOWLEDGEMENTS}

Cagnoli, Claudia. She holds a fellowship from Agencia Nacional de Promoción Científica y Tecnológica. Ministerio de Ciencia y Tecnología. República Argentina.

CHIAPPARRONE, M. L.; SOTO, P. \& CATENA, M. Caracterización de la adhesión de Campylobacter fetus subsp. venerealis a espermatozoides bovinos. Int. J. Morphol., 34(4):1419-1423, 2016.

RESUMEN: Campylobacter fetus subsp. venerealis es un patógeno extracelular del tracto genital de bovinos. En las hembras causa subfertilidad y aborto, mientras que los toros son portadores en el esmegma prepucial y se desconoce si provoca daño en los espermatozoides. El objetivo del presente trabajo fue estudiar los efectos de Campylobacter fetus subsp. venerealis sobre espermatozoides bovinos. Los espermatozoides obtenidos a partir de pajuelas de semen pertenecientes a toros no infectados, se coincubaron con una cepa de Campylobacter fetus subsp. venerealis por diferentes períodos de tiempo. Por microscopía óptica y electrónica de barrido se observó el tropismo inicial de la bacteria hacia los espermatozoides y la adhesión bacteriana, de forma colateral se observó su efecto en el espermograma. Post incubación los espermatozoides presentaron menor motilidad progresiva y mayor porcentaje de muertos con respecto al control. Se comprobó la viabilidad de la bacteria a las $3 \mathrm{~h}$. Se registró la adhesión de Campylobacter fetus subsp. venerealis a la membrana celular de distintas porciones del espermatozoide: cabeza, pieza media, cuello y cola. Los resultados de este estudio permitieron caracterizar la interacción entre Campylobacter fetus subsp. venerealis y espermatozoides bovinos por microscopía óptica y electrónica de barrido. La aplicación de este modelo ex vivo permitirá profundizar los conocimientos referentes a los procesos de adhesión y citopatogenicidad de Campylobacter fetus.

PALABRAS CLAVE: Adhesión; Campylobacter fetus subsp. Venerealis; Espermatozoides.

\section{REFERENCES}

Barth, A. D. Evaluation of Frozen Bovine Semen by the Veterinary Practitioner. In: Proceedings of the Bovine Short Course. Hastings, American College of Theriogenologists and Society for Theriogenology, 1995.

Benchimol, M.; de Andrade Rosa, I.; da Silva Fontes, R. \& Burla Dias, A. J. Trichomonas adhere and phagocytose sperm cells: adhesion seems to be a prominent stage during interaction. Parasitol. Res., 102(4):597-604, 2008.

Bhavsar, S. \& Kapadnis, B. Virulence factors of Campylobacter. Internet J. Microbiol., 3(2):1-7, 2006.
Bielanski, A. \& Dubuc, C. In vitro fertilization of bovine oocytes exposed to Bovine Herpesvirus-1 (BHV-1). Reprod. Domest. Anim., 28(4):285-8, 1993.

Bielanski, A.; Sampath, M.; Gradil, C.; Eaglesome, M. D. \& Garcia, M. In vitro fertilization of bovine ova in the presence of Campylobacter fetus subsp. venerealis. Reprod. Domest. Anim., 29(6):488-93, 1994.

Bielanski, A. \& Dubuc, C. In vitro fertilization and culture of ova from heifers infected with bovine herpesvirus-1 (BHV1). Theriogenology, 41(6):1211-7, 1994.

Bielanski, A. \& Loewen, K. In vitro fertilization of bovine oocytes with semen from bulls persistently infected with bovine viral diarrhea virus. Anim. Reprod. Sci., 35(3-4):183-9, 1994.

Bielanski, A.; Ghazi, D. F. \& Phipps-Toodd, B. Observations on the fertilization and development of preimplantation bovine embryos in vitro in the presence of Tritrichomonas foetus. Theriogenology, 61(5):821-9, 2004.

Campero, C. M. Pérdidas ocasionadas por las enfermedades venéreas de los bovinos. Rev. IDIA (Bs. As.), 21(2):127-31, 2002.

Casadevall, A. \& Pirofski, L. A. Host-pathogen interactions: basic concepts of microbial commensalism, colonization, infection, and disease. Infect. Immun., 68(12):6511-8, 2000.

Catena, M. Campilobacteriosis Genital Bovina: Inmunopatogenia de la Mortalidad Embrionaria. Tesis Doctoral en Ciencia Animal. Facultad de Ciencias Veterinarias. Tandil, Universidad Nacional del Centro de la Provincia de Buenos Aires, 2002.

Catena, M.; Callejas, S.; Soto, P.; Aba, M.; Echevarría, H.; Monteavaro, C. \& Mazzolli, A. Efectos de la infección experimental con Campylobacter fetus venerealis sobre la preñez temprana en vaquillonas. Invest. Vet., 5(1):37-44, 2003.

Chiapparrone, M. L.; Catena, M.; Rodríguez, E.; Echevarría, H.; Monteavaro, C.; Morán, P.; Arroyo, G. \& Soto, P. Evaluación de la Adhesión de Campylobacter fetus venerealis en Diferentes Líneas Celulares. Rosario, Libro de Resúmenes de las XIII Jornadas Argentinas de Microbiología, Rosario, Santa Fe, Argentina, 2008. pp.181.

Chiapparrone, M. L.; Catena, M.; Morán, P.; Teruel, M.; Echevarría, H. \& Soto, P. Modelos de Estudio In Vitro para Campylobacter fetus. Mar del Plata, Libro de Resúmenes del IV Encuentro de Biólogos en Red, Mar del Plata, Argentina, 2009. pp.24.

Chiapparrone, M. L.; Morán, P. E.; Pasucci, J. A.; Echevarría, H. M.; Monteavaro, C.; Soto, P.; Rodríguez, E. M. \& Catena, M. C. Quantitative analysis of Campylobacter fetus venerealis adhesion to bovine reproductive tract cell cultures. Braz. J. Vet. Res. Anim. Sci., 48(1):73-8, 2011. 
Chiapparrone, M. L.; Morán, P. E.; Echevarría, H. M.; Soto, P.; Paolicchi, F. A. \& Catena, M. Campylobacter fetus subsp. venerealis adhesion to MDBK cells. Rev. Argent. Microbiol., 46(3):269-70, 2014.

de Melo, M. A. \& Pechère, J. C. Identification of Campylobacter jejuni surface proteins that bind to Eucaryotic cells in vitro. Infect. Immun., 58(6):1749-56, 1990.

Fletcher, M. \& Floodgate, G. D. An electron-microscopic demonstration of an acidic polysaccharide involved in the adhesion of a marine bacterium to solid surfaces. J. Gen. Microbiol., 74:325-34, 1973.

Garrity, G.; Brenner, D. J.; Krieg, N. R. \& Staley, J. T. Bergey's Manual of Systematic Bacteriology. Volumen 2: The Proteobacteria (Part C). Family I Campylobacteraceae. Genus I Campylobacter. New York, Springer-Verlag US, 2nd ed. 2005. pp.1145-60.

Graham, L. L. \& MacDonald, K. L. The Campylobacter fetus S layer is not essential for initial interaction with HEp-2 cells. Can. J. Microbiol., 44(3):244-50, 1988.

Joens, L. A.; Haesebrouck, F. \& Pasmans, F. Campylobacter. In: Gyles, C. L.; Prescott, J. F.; Songer, J. G. \& Thoen, C. O. (Eds.). Pathogenesis of Bacterial Infections in Animals. $4^{\text {th }}$ ed. Ames, Wiley-Blackwell, 2010. pp.483-501.

Rodríguez-Martínez, H. Semen evaluation techniques and their relationship with fertility. Anim. Reprod., 10(3):148-59, 2013.

\author{
Corresponde to: \\ María L. Chiapparrone \\ CONICET-CIVETAN \\ Área de Enfermedades Infecciosas. \\ Departamento de Sanidad Animal y Medicina Preventiva \\ Facultad de Ciencias Veterinarias \\ UNCPBA \\ Paraje Arroyo Seco S/N \\ CP 7000 \\ Tandil \\ ARGENTINA \\ E-mail: mlchiapp@vet.unicen.edu.ar
}

Received: 14-07-2016

Accepted: 14-10-2016 